Dunamis: Jurnal Teologi dan Pendidikan Kristiani

Volume 4, Nomor 1 (Oktober 2019)

ISSN 2541-3937 (print), 2541-3945 (online)

http://www.sttintheos.ac.id/e-journal/index.php/dunamis

Submitted: 18 Juli 2019

Accepted: 3 Oktober 2019

Published: 28 Oktober 2019

\title{
Beyond the Language: Sebuah Studi Analisis Dan Komparasi antara Konsep Bahasa Roh dalam Teologi Pentakosta dengan Konsep Rede dalam Filsafat Martin Heidegger
}

\author{
Jessica Novia Layantara \\ Program Studi Manajemen Perhotelan Universitas Pelita Harapan \\ jessica.layantara@uph.edu
}

\begin{abstract}
This article discusses the comparison between the concepts of speaking in tongues in Pentecostal theology and the concept of Rede in the philosophy of Martin Heidegger. The thesis of this article was that the concept of speaking in tongues in Pentecostal theology had many similarities to the concept of Rede in Heidegger's philosophy. The similarities were found in the characters in both concepts, which were communicative, intelligible, revealing and both were authentic human characters (Dasein). Nevertheless, the concept of speaking in tongues in Pentecostal theology had a uniqueness over the concept of Rede in Heidegger's philosophy, because it encompassed not only the human rationality, but also the realm of faith. In this article it was shown that the two concepts influenced and enriched each other. This comparative study also yielded some conceptual contributions to both Pentecostal theology and Heidegger's philosophy, which were also useful for dealing with the criticisms raised against both.
\end{abstract}

Keywords: speaking in tongues; Pentecostal theology; rede; gerede; Martin Heidegger

\begin{abstract}
Abstrak
Artikel ini membahas komparasi antara konsep bahasa roh dalam teologi Pentakosta dengan konsep Rede dalam filsafat Martin Heidegger. Tesis dari artikel ini adalah bahwa konsep bahasa roh dalam teologi Pentakosta memiliki banyak kemiripan dengan konsep Rede dalam filsafat Heidegger. Kemiripan-kemiripan tersebut terdapat dalam karakter-karakter yang ada di dalam kedua konsep tersebut, antara lain sama-sama bersifat komunikatif, bersifat menyingkapkan, dapat dimengerti, dan keduanya merupakan karakter dari manusia yang otentik (Dasein). Walau demikian, konsep bahasa roh dalam teologi Pentakosta memiliki kekhasan dibanding konsep Rede dalam filsafat Heidegger, karena bukan hanya mencakup ranah rasionalitas manusia tetapi juga ranah iman. Di dalam artikel ini akan ditunjukkan bahwa kedua konsep tersebut dapat saling mempengaruhi dan memperkaya satu sama lain. Studi komparasi ini juga akan menghasilkan beberapa kontribusi yang bermanfaat secara konseptual baik bagi teologi Pentakosta maupun filsafat Heidegger, yang juga bermanfaat untuk menghadapi kritik-kritik yang diajukan terhadap keduanya.
\end{abstract}

Kata Kunci: bahasa roh; teologi Pentakosta; rede; gerede; Martin Heidegger 


\section{PENDAHULUAN}

Bahasa roh adalah fenomena yang sangat penting dalam teologi Pentakosta. ${ }^{1}$ Menurut teologi Pentakosta, bahasa roh bukan sekadar praktik yang tidak bermakna dalam kehidupan orang Kristen. Sebaliknya, bahasa roh dipandang sebagai tanda utama dan normatif dalam baptisan Roh Kudus. ${ }^{2}$ Bahasa roh dalam teologi Pentakosta juga dipandang sebagai karunia universal yang seharusnya didapatkan oleh semua orang Kristen sampai zaman sekarang. ${ }^{3}$

Kepercayaan bahwa bahasa roh adalah karunia universal dan masih relevan membuat praktik berbahasa roh masih berlangsung dalam gereja-gereja Pentakosta. Praktik ini terlihat dalam kebaktian-kebaktian Gereja Pentakosta maupun dalam doa-doa pribadi jemaat. Bentuk dan lafal bahasa roh dapat beraneka ragam. Ada bahasa roh yang berbentuk bahasa-bahasa yang tidak dipelajari sebelumnya oleh si pembicara. Di sisi lain, ada juga bahasa roh yang berbentuk ucapan-ucapan yang tidak dapat dimengerti

\footnotetext{
${ }^{1}$ Meskipun istilah yang lebih sering digunakan dalam artikel-artikel teologis adalah "bahasa lidah" dan bukan "bahasa roh," penulis memilih untuk menggunakan istilah "bahasa roh" sesuai dengan yang digunakan di dalam Alkitab LAI.

${ }^{2}$ Craig S. Keener, Gift and Giver: The Holy Spirit for Today (Michigan: Baker Academic, 2001), 183.
}

karena bersifat non-linguistik dan tidak memiliki makna yang jelas. Lafal yang diucapkan pun beraneka ragam, ada yang seragam namun ada pula yang tidak. Namun demikian, beberapa penelitian membuktikan bahwa seseorang yang berbahasa roh mengucapkannya dalam keadaan sadar. Oleh sebab itu, bahasa roh tidak dapat digolongkan menjadi sesuatu yang terlontar begitu saja saat seseorang berada dalam keadaan trance. ${ }^{4}$

Bentuk bahasa roh yang dilakukan secara spontan dan prareflektif tersebut membuat penulis tertarik untuk membandingkan konsep bahasa roh di dalam teologi Pentakosta dengan konsep filsafat Heidegger yang disebut Rede. Rede di dalam filsafat Heidegger bukan sekadar berarti "pembicaraan," melainkan "pembicaraan yang menyingkapkan." Sedikit banyak penulis menemukan beberapa kemiripan antara konsep bahasa roh dan Rede, antara lain sama-sama dapat bersifat lingustik maupun non-linguistik, bersifat komunikatif, bersifat menyingkapkan, otentik, dan dapat menyampaikan maksud orang yang

\footnotetext{
${ }^{3}$ Craig S. Keener, Spirit Hermeneutics: Reading Scripture in Light of Pentecost (Michigan: Wm. Eerdmans Publishing Co, 2016), 55.

${ }^{4}$ Scott Semeyna and Rodney Schmaltz, "Glossolalia Meets Glosso-Psychology: Why Speaking in Tongues Persist in Charismatic Christian and Pentecostal Gathering," Skeptic Magazine 17, no. 4 (2012): 41.
} 
mengatakannya. Namun demikian, tentu saja keduanya tidak dapat dikatakan identik, karena penulis juga menemukan perbedaan-perbedaan yang khusus dan esensial di dalam konsep bahasa roh maupun di dalam konsep Rede.

Artikel ini bertujuan untuk mengkomparasi antara konsep bahasa roh menurut teologi Pentakosta dan konsep Rede dalam filsafat Heidegger. Penulis berharap melalui artikel ini, relasi salingbertautan antara teologi dan filsafat dapat diperlihatkan dengan jelas.

\section{METODE PENELITIAN}

Metode yang digunakan dalam artikel ini adalah dengan menganalisis dan membandingkan teori melalui penelitian kepustakaan (library research). Metode penelitian kepustakaan akan dilakukan melalui pengumpulan data-data kepustakaan seperti buku-buku, jurnaljurnal dan sumber-sumber daring.

Metode analisa dan komparasi akan dilakukan berdasarkan dua landasan teori yang akan dijabarkan lebih lanjut, yaitu pandangan teologi Pentakosta mengenai bahasa roh dan pandangan Heidegger mengenai Rede. Kedua teori tersebut kemudian akan dikomparasi dengan cara mencari kesamaan-kesamaan dan perbedaan-perbedaan di antara keduanya.
Pada akhirnya, penulis juga akan mensintesiskan hasil komparasi yang telah diteliti di dalam artikel ini, serta memaparkan beberapa kontribusi konseptual yang dapat diambil dari penelitian ini.

\section{HASIL DAN PEMBAHASAN}

\section{Pandangan Teologi Pentakosta mengenai Bahasa Roh}

Istilah bahasa roh atau glossolalia, yang sering menjadi istilah yang umum dalam teologi Pentakosta berasal dari penggabungan kata Yunani glossa (lidah, bahasa) dan laleo (mengucapkan, mengungkapkan). Istilah glossolalia sendiri tidak terdapat di dalam Alkitab, namun kata glossa dan laleo secara terpisah dipakai berkaitan dengan praktik berbahasa roh (speaking in tongues) dalam gereja perdana (Kis. 2:4), "Maka penuhlah mereka dengan Roh Kudus, lalu mereka mulai berkata-kata dalam bahasa-bahasa lain, seperti yang diberikan oleh Roh itu kepada mereka untuk mengatakannya" (TB-LAI). Frasa "berkata-kata" menggunakan kata Yunani "laleo," sedangkan frasa "bahasa-bahasa lain" menggunakan kata "glossa."

Seperti yang dijelaskan sebelumnya, para pendiri gerakan Pentakosta selalu mengasosiasikan bahasa roh dengan baptisan Roh Kudus. Bahasa 
roh di dalam teologi Pentakosta dipandang sebagai satu-satunya tanda seseorang telah menerima baptisan Roh Kudus. Pandangan ini didasarkan atas beberapa perikop di dalam Alkitab, khususnya di dalam Kisah Para Rasul yang ditulis oleh Lukas. Di dalam Kisah Para Rasul, ada beberapa momen yang menunjukkan terjadinya fenomena bahasa roh saat seseorang menerima baptisan Roh Kudus, antara lain di dalam peristiwa Pentakosta (Kis. 2), rumah Kornelius (Kis. 10), dan di Efesus (Kis. 19). Selain itu, Rasul Paulus juga tidak melarang pemakaian bahasa roh di dalam gereja perdana (1 Kor. 14:39), sekalipun ia sempat menegur gereja di Korintus karena menyalahgunakan karunia ini (1 Kor. 1214). Namun inti dari pemberitaan Lukas dan Paulus, menurut Evan Siahaan, adalah sama-sama mendukung adanya fenomena bahasa roh dalam gereja mula-mula. Siahaan berkata,

Sekalipun ada perbedaan konsep dan konteks bahasa roh yang muncul dalam Kisah Para Rasul 2:113 dengan yang dijelaskan Paulus dalam I Kor. 12-14, namun tidak bisa dipungkiri bahwa keduanya, sejatinya, merupakan peristiwa dari karya dan manifestasi Roh Kudus, yang secara terminologi - baik Lukas maupun Paulus -

\footnotetext{
${ }^{5}$ Harls Evan R. Siahaan, "Refleksi Alkitabiah Fenomena Glossolalia," Jurnal Antusias 2, no. 1 (2012): 160-179, accessed October 22, 2019, https://sttintheos.ac.id/ejournal/index.php/antusias/article/view/67.
}

menggunakan istilah glossolalia, atau yang di(per)kenal(kan) LAI sebagai bahasa roh. ${ }^{5}$

Lebih jauh lagi, teologi Pentakosta juga meyakini bahwa fenomena berbahasa roh ini bukan hanya berlangsung di zaman gereja perdana, melainkan tetap berlangsung sampai hari ini. ${ }^{6}$ Robert Menzies menegaskan bahwa semua orang yang percaya kepada Kristus dan telah dibaptis Roh Kudus seharusnya bisa berbahasa roh, sehingga sifat bahasa roh ini adalah universal bagi gereja dan valid sampai zaman sekarang. ${ }^{7}$

Charles Parham, tokoh sentral dalam sejarah gerakan Pentakosta, adalah orang pertama yang mengajarkan bahwa karunia bahasa roh yang terdapat dalam Alkitab masih berlangsung sampai zaman sekarang. Parham juga adalah orang pertama yang mengasosiasikan karunia bahasa roh dengan baptisan Roh Kudus. Ajaran mengenai bahasa roh tersebut masih dilanjutkan oleh William Seymour, murid Parham, yang juga merupakan tokoh sentral dalam peristiwa di Azusa Street. Kebangunan rohani di Azusa Street merupakan peristiwa yang sangat

\footnotetext{
${ }^{6}$ Keener, Spirit Hermeneutics: Reading Scripture in Light of Pentecost, 55.

${ }^{7}$ Robert P. Menzies, "The Role of Glossolalia in Luke-Acts," AJPS 15, no. 1 (2012): 49.
} 
bersejarah dalam teologi Pentakosta. Gerakan ini dimulai oleh William Seymour, seorang kulit hitam yang juga adalah salah seorang murid Charles Parham. Pada tahun 1906, bertempat di sebuah bangunan di Azusa Street, Los Angeles, California, diadakan pertemuan ibadah yang dihadiri oleh banyak orang Kristen. Di dalam pertemuan ibadah itu, Seymour berkhotbah mengenai baptisan Roh Kudus harus ditandai dengan karunia berbahasa roh. Setelah mendengar khotbah tersebut, banyak jemaat yang tiba-tiba dapat berbahasa roh disertai manifestasimanifestasi lainnya seperti menari, bernyanyi, berteriak, dan bernubuat. Pertemuan di Azusa Street menjadi sangat fenomenal di zamannya, ditandai dengan semakin banyaknya orang yang datang ke pertemuan ibadah tersebut. Bahkan setelah gerakan Pentakosta terbagi menjadi kelompok yang lebih memegang tradisi Trinitarian dan kelompok Oneness Pentecostal, yaitu aliran Pentakosta yang tidak mempercayai bahwa Bapa dan Anak adalah Pribadi yang berbeda, ${ }^{8}$ ajaran mengenai bahasa roh terus diajarkan dan menjadi salah satu ciri khas bagi teologi

\footnotetext{
${ }^{8}$ Peter Hocken, The Challenges of the Pentecostal, Charismatic and Messianic Jewish Movement: The Tension of the Spirit (Farnham: Ashgate Publishing Limited, 2009), 23.

${ }^{9}$ Fredrick Dale Bruner, A Theology of the Holy Spirit: The Pentecostal Exprerience and the New
}

Pentakosta dibandingkan ajaran-ajaran denominasi lain. Menurut Frederick Dale Brunner, pengajaran mengenai bahasa roh ini juga menampilkan keunikan terjelas di dalam doktrin Pentakosta yang membedakan aliran ini dengan aliran-aliran Kristen arus utama. ${ }^{9}$

Keyakinan bahwa karunia bahasa roh ini masih berlangsung membuat gerejagereja Pentakosta saat ini masih mempraktikkan bahasa roh, terutama dalam doa, baik doa yang dilakukan secara pribadi maupun secara berjamaah, dengan syarat tidak mengganggu ketertiban ibadah. Alexander O. Sign menegaskan bahwa seseorang yang ingin berbahasa roh dalam jemaat harus benar-benar memiliki pesan untuk jemaat, dan jika tidak, ia hanya boleh berbahasa roh secara pelan dan pribadi. ${ }^{10}$ Praktik berbahasa roh ini terkadang dibarengi dengan berbagai manifestasi yang lain. Neil Hudson mengatakan, "The exotic nature of these experiences cannot be overemphasised. Strange languages, awesome mystical visions, physical responses of being overwhelmed and falling to the floor, being overcome with tears or

Testament Witness (Michigan: Eerdmans Publishing Company, 1982), 77.

${ }^{10}$ Alexander O. Sign, Speaking in Tongues

(Bloomington: AuthorHouse, 2014), 102. 
laughter were included in a heady mix for these early Pentecostals." 11

Dalam praktiknya, bahasa roh dapat dibedakan menjadi dua jenis. Jenis pertama yaitu ketika seseorang mengucapkan bahasa-bahasa bangsa lain yang tidak pernah ia pelajari sebelumnya, yang diyakini sebagai pemberian Roh Kudus. Fenomena yang biasa disebut sebagai xenolalia (xeno: bahasa, laleo: mengucapkan) ini dapat ditemukan di dalam peristiwa Pentakosta (Kis. 2), di mana orang-orang yang berkumpul di Yerusalem mulai berbahasa dalam "bahasabahasa mereka sendiri" (Kis. 2:6), dan ada yang dapat mengenali bahasa-bahasa lain yang diucapkan para murid bahkan mengerti bahwa para murid itu sedang menceritakan perbuatan-perbuatan besar yang dilakukan Allah (Kis. 2:7-11). Pengalaman ini juga diyakini masih berlangsung pasca zaman rasul-rasul dan sampai zaman sekarang. Hermanto Suanglangi menyetujui bahwa fenomena xenolalia masih berlangsung sampai saat ini, karena "Roh Kudus tidak mungkin dibatasi bekerja, dan banyak peristiwa yang

\footnotetext{
${ }^{11}$ Neil Hudson, "Dealing with the Fire: Early Pentecostal Responses to the Practices of Speaking in Tongues and Spoken Prophecy," Journal of the European Pentecostal Theological Association 28, no. 2 (2008): 145-157.

${ }^{12}$ Hermanto Suanglangi, "Bahasa Roh: Apa Dan Bagaimana?," Jurnal Jaffray 2, no. 1 (April 1, 2005): 17.
}

terjadi di zaman sekarang."12 Charles Parham sendiri menyatakan bahwa dirinya sempat mengalami fenomena tersebut di zaman sekarang, "A glory fell over me and I began to worship God in the Swedish tongue, which later changed to other languages and continued so until the morning." 13

Namun, barangkali yang sering menjadi perdebatan adalah bahasa roh jenis yang kedua, yaitu ketika seseorang mengucapkan bahasa-bahasa lain yang tidak dapat dimengerti oleh manusia. Di dalam 1 Korintus 12-14, Paulus menyiratkan bahwa Roh Kudus memberikan bahasa-bahasa yang tidak dimengerti oleh manusia untuk diucapkan. Ervin Budiselic, bersama dengan penganut teologi Pentakosta, meyakini bahasabahasa ini bukan bahasa manusia, dan kadang disebut sebagai "bahasa para malaikat."14 Menurut Menzies, ini terbukti ketika Paulus menyarankan agar semua ucapan dalam bahasa-bahasa lain itu diterjemahkan, dan untuk itu diperlukan

\footnotetext{
${ }^{13}$ Sarah E. Parham, The Life of Charles F. Parham, Founder of the Apostolic Faith Movement (Baxter Springs, KS: Apostolic Faith Bible College, 1930), 54.

${ }^{14}$ Ervin Budiselic, "Glossolalia: Why Christians Can Speak in Tongues in a Church Service without Interpretation," Kairos Evangelical Journal of Theology 10, no. 2 (2016): 179.
} 
sebuah karunia khusus untuk menerjemahkan bahasa roh. ${ }^{15}$

Fenomena glossolalia juga diyakini masih berlangsung sampai saat ini. Warren Carothers, seorang pengikut Parham, menyatakan,

Tongues... are praises to God in language, peculiarly acceptable to Him for the reason that He forms the words, and there is abundant use for the tongue whether any man understands him or not, in fact the inevitable inference from St. Paul's statement is that it is not primarily intended that any man should understand the tongues. ${ }^{16}$

Bahasa roh jenis kedua ini tidak memiliki struktur bahasa yang jelas, serta tidak menyiratkan ada artikulasi tertentu yang harus diucapkan seseorang. Lafal-lafal yang diucapkan juga tidak selalu seragam, namun setidaknya penelitian telah merangkumkan beberapa artikulasi yang pernah muncul, dari yang sederhana sampai yang rumit:

Nanananananana.

Labalabalaba labalaba.

\footnotetext{
${ }^{15}$ Menzies, "The Role of Glossolalia in LukeActs," 50.

${ }^{16}$ Warren F. Carothers, The Baptism with the Holy Ghost and the Speaking in Tongues (Zion City, IL, 1906), 21.

${ }^{17}$ Gonti Simanullang, "Baptism in the Holy Spirit: A Phenomenological and Theological Study" (Melbourne College of Divinity, 2012), accessed October 22, 2019,

https://repository.divinity.edu.au/931/.
}

Riarayarariarayara. ${ }^{17}$

Kasiasia iya kisia si.

Veni veni veni cristia simira veniria crista ven a amiria asaria abi veni aria. $^{18}$

Bule te skuru te sinte omkoton, stinte te leteo de tinka ong, lepe lute impre sute comp intope. ${ }^{19}$

Di dalam praktiknya, bahasa roh digunakan berkaitan dengan tiga tujuan yang disebutkan di dalam Alkitab. Pertama, untuk berdoa secara pribadi, khususnya untuk menyampaikan keluhan-keluhan yang tidak terucapkan (Rom. 8:26, I Kor. 14:2). Kedua, bahasa roh digunakan juga di dalam ibadah sebagai sebuah sakramen Pentakostal yang, menurut Menzies, adalah "sebuah sakramen yang memiliki demokratisasi yang penuh kuasa bagi kehidupan gereja."20 Ketiga, bahasa roh digunakan untuk tujuan misiologis, di mana tujuan ini menekankan sifat bahasa roh yang demonstratif. Robert Menzies mengatakan, "Namun karena berbicara

\footnotetext{
${ }^{18}$ Data Glossolalia dari Cuarta Iglesia (1968) and Lorenzo (1970). Felicitas D. Goodman, Speaking in Tongues: A Cross-Cultural Study of Glossolalia (Oregon: WIPF\&Stock, 1972), 119-120.

${ }^{19}$ Semeyna and Schmaltz, "Glossolalia Meets Glosso-Psychology: Why Speaking in Tongues Persist in Charismatic Christian and Pentecostal Gathering," 40.

${ }^{20}$ William P. Menzies and Robert P. Menzies, Roh Kudus Dan Kuasa: Dasar-Dasar Pengalaman Pentakostal (Batam: Gospel Press, 2005), 189.
} 
dalam bahasa roh itu tidak biasa dan sifatnya demonstratif (yang menjadi alasan mengapa bahasa roh sering difitnah dan dilebih-lebihkan), sangat cocok untuk diterima sebagai bukti."21 Namun selain tiga alasan ini, menurut Jacob D. Dodson, kaum Pentakosta meyakini bahwa berbahasa roh membawa manfaat khusus bagi kerohanian mereka, seperti meningkatkan spiritualitas dan kedekatan mereka dengan Tuhan. ${ }^{22}$

\section{Konsep Rede di dalam Filsafat Heidegger}

Konsep bahasa roh yang dianut oleh teologi Pentakosta memiliki kemiripan dengan konsep Rede di dalam filsafat Martin Heidegger. Sebelum membahas mengenai kemiripan-kemiripan dan perbedaan-perbedaan yang dimiliki oleh bahasa roh dan Rede, bagian ini akan terlebih dahulu membahas secara ringkas pandangan Heidegger mengenai konsep Rede.

Kata Rede di dalam bahasa Jerman secara literal dapat diartikan sebagai pembicaraan (talk, discourse) atau percakapan (conversation). Namun konsep Rede di dalam filsafat Heidegger memiliki

21 Ibid, 183.

22 Jacob D. Dodson, "Gifted for Change: The Evolving Vision for Tongues, Prophecy, and Other Charism in American Pentecostal Church," Studies in the World Christianity 17, no. 1 (2011): 56. makna yang berbeda dari arti literalnya. Secara sederhana, Rede di dalam filsafat Heidegger dapat diartikan sebagai artikulasi atau ungkapan atas sesuatu yang dimaknai (articulation of intelligibility). ${ }^{23}$ Artikulasi di sini tidak selalu harus diartikan sebagai ungkapan linguistik. Bahkan Rede di dalam filsafat Heidegger adalah dasar dari terbentuknya bahasa. ${ }^{24}$ Bisa dikatakan Rede merupakan pre-language, atau asal-usul dari bahasa manusia yang digunakan seharihari. Ibarat seorang bayi yang di dalam pikirannya bermaksud meminta susu dari ibunya, namun belum dapat berbahasa, bayi tersebut tetap akan mengeluarkan bunyi atau suara yang non-linguistik untuk menyatakan maksudnya. Sifat dari suara yang dikeluarkan bayi tersebut dapat dikatakan sebagai artikulasi yang bersifat pre-language, tetapi bukan berarti tanpa makna. Artikulasi non-linguistik yang diungkapkan bayi tersebut merupakan pengungkapan makna dari keinginan bayi tersebut akan susu.

Karakteristik kedua dari Rede adalah sifatnya yang komunikatif. Artikulasi dari bayi tersebut di atas tetap dapat dikatakan komunikatif walaupun

\footnotetext{
${ }^{23}$ Martin Heidegger, Being and Time, trans. John Macquarrie and Edward Robinson (Oxford: Basil Blackwell, 1962), 203.

${ }^{24}$ Ibid, 202.
} 
orang lain tidak mengerti apa yang sedang dibicarakan oleh bayi tersebut. Selama bayi tersebut mengeluarkan suara dalam tujuan komunikasi dan di dalam pikirannya terkandung pengertian mengenai apa yang ia katakan, maka itu tetap tergolong sebagai komunikasi. Mark Ockrent berpendapat bahwa bagi Heidegger, semua Rede bersifat komunikatif, tetapi yang dimaksud komunikasi di sini tidak melulu merupakan pertukaran informasi, melainkan saling berbagi artikulasi pun sudah dapat digolongkan sebagai sebuah bentuk komunikasi. $^{25}$ Lebih lagi, Heidegger menekankan bahwa Rede adalah komunikasi, karena menurutnya komunikasi tidak selalu mensyaratkan salah satu pihak untuk memahami komunikasi dari pihak lainnya. ${ }^{26}$ Komunikasi di dalam Rede bukanlah komunikasi untuk menyampaikan pengalaman, opini, atau keinginan kita pada subyek lainnya, melainkan sebuah pengungkapan seseorang bahwa ia berada-dalam-dunia (being-inthe-world). ${ }^{27}$ Jadi Rede adalah komunikasi karena ia merupakan "usaha untuk menyampaikan atau memberitakan sesuatu dari "Ada"-nya." 28

\footnotetext{
${ }^{25}$ Mark Okrent, “On Layer Cakes: Heidegger's Normative Pragmatism Revisited," in Pragmatic Perspectives in Phenomenology, ed. Ondrej Svec and Jakub Capek (New York: Routledge, 2017), 33. ${ }^{26}$ Ibid, 110.

${ }^{27}$ Heidegger, Being and Time, 205.
}

Selain bersifat komunikatif, Rede juga memiliki karakteristik menyingkapkan sesuatu. Karakteristik ini digarisbawahi oleh Heidegger saat ia mengasosiasikan kata Rede dengan Logos. Logos berasal dari bahasa Yunani yang dapat berarti "perkataan," "logika," "definisi," atau “prinsip.” Aristoteles menggunakan kata ini untuk memberikan makna pengungkapan akan sesuatu. Bagi Aristoteles, Logos selalu memiliki karakter pengungkapan. Dengan kesan yang sama, Heidegger mengasosiasikan Logos dengan Rede yang memiliki karakter menyingkapkan sesuatu. Sembera mengatakan, "Following Aristotle, Heidegger sees the essential feature of Logos or "talk" as the ability to reveal that which is talked about, the ability to indicate something, to make one aware of it."29 Rede yang diajukan Heidegger memiliki makna yang hampir sama dengan Logos, terutama dalam karakter bahwa Rede dan Logos sama-sama memiliki tujuan untuk mengungkapkan sesuatu. Logos, seperti Rede, tidak harus berupa bahasa linguistik, namun selalu bersifat mengungkapkan sesuatu.

\footnotetext{
${ }^{28}$ F. Budi Hardiman, Heidegger Dan Mistik Keseharian (Jakarta: Kepustakaan Populer Gramedia, 2016), 96.

${ }^{29}$ Richard Sembera, Rephrasing Heidegger: A Companion to Being and Time (Ottawa: The University of Ottawa Press, 2007), 56.
} 
Karakteristik "menyingkapkan sesuatu" ini, menurut Heidegger, paralel dengan karakteristik manusia otentik atau Dasein. Dasein adalah manusia ideal dalam filsafat Heideggerian, yang merujuk pada manusia otentik, yang bukan hanya terlibat dalam kesibukan sehari-hari, melainkan manusia yang selalu mencoba mengeksplorasi "ada"-nya. Ciri dari Dasein adalah keterbukaan dan selalu ingin mengerti lebih jauh mengenai keberadaan (Being) dirinya. Heidegger mengkontraskan Dasein dengan Dasman, yaitu manusia yang tidak otentik yang identik dengan kelupaan pada otentisitas dan keterlemparannya dalam dunia (kesibukan, pembicaraan-pembicaraan ringan, interaksi-interaksi sosial yang tidak ada habisnya). Oleh sebab itu, seorang Dasein (manusia yang otentik) pasti selalu memiliki Rede sebagai salah satu karakter esensialnya karena Dasein selalu bersifat terbuka dan terungkap. Rede sebagai karakter esensial Dasein sama fundamentalnya dengan karakter esensial Dasein yang lain, yaitu keadaan pikiran (befindlichkeit) atau pemahaman seseorang (verstehen). Heidegger berkata, "Discourse (Rede) is existentially equiprimordial with

\footnotetext{
${ }^{30}$ Heidegger, Being and Time, 171, 203.

${ }^{31}$ Ibid, 203.
}

disposeness (sensibility, red) and understanding. $" 30$

Pengungkapan Rede ini bersifat primordial, lebih primordial dari interpretasi atau pernyataan yang dibuat oleh seseorang. Bahkan Rede dijadikan sebagai dasar dari interpretasi atau pernyataan seseorang. ${ }^{31}$ Hal ini bukan hanya dikarenakan Rede tidak selalu bersifat linguistik, melainkan karena Rede bersifat pra-reflektif. Akan tetapi, yang pasti, Rede selalu diungkapkan melalui artikulasi-artikulasi non verbal. Tahap selanjutnya dari Rede adalah bahasa (Sprache), yang kemudian digunakan untuk menginterpretasi dan menyatakan sesuatu secara linguistik. F. Budi Hardiman berargumen, "Percakapan (Rede) bukanlah komunikasi verbal, melainkan suatu penyampaian makna yang mendahului artikulasinya dalam bahasa (sprache).,"32 Artinya, Rede bukanlah sebuah bahasa, yang memiliki gramatika dan verbal, melainkan Rede adalah sebuah pra-bahasa, dan merupakan asal-usul dari bahasa.

Pengungkapan Rede harus selalu bersifat komunikatif, dalam arti, Rede harus diungkapkan di hadapan pihak lain dan tidak dapat dijadikan sebagai percakapan di dalam hati. Paul Gorner mengatakan,

\footnotetext{
${ }^{32}$ Hardiman, Heidegger Dan Mistik Keseharian, 87.
} 
"Discourse (Rede) is expression or making known (Bekundung). In discourse Dasein 'speaks itself out'." ${ }^{33}$ Secara sederhana, Taylor Carman mengatakan, "Discourse (Rede), apparently, consists essentially in saying something about something to someone." 34

Rede di dalam filsafat Heidegger dikontraskan dengan konsep mengenai Gerede. Dalam bahasa Jerman, secara literal Gerede berarti "rumour bearing talk" atau "gossip." 35 Dalam filsafat Heidegger, Gerede dapat diartikan sebagai perkataan yang tidak bermakna (idle talk). Richard Sembera menambahkan bahwa imbuhan ge- yang diletakkan sebelum kata Rede memiliki makna kolektif, sehingga dalam filsafat Heidegger sangat cocok jika Gerede diartikan sebagai perkataan yang disalurkan kepada orang lain secara kolektif (mass talk) atau percakapan sehari-hari yang santai (casual conversation). Sembera mengatakan, "Gerede, for Heidegger, will thus mean something along the lines of ' $a$ mass of talk,' 'talk for talk's sake,' 'chatter.' Its main structural feature is that it obscures what is being talked about. For this reason, it seemed most appropriate to

\footnotetext{
${ }^{33}$ Paul Gorner, Heidegger's Being and Time: An Introduction (Cambridge: Cambridge University Press, 2007), 90.

${ }^{34}$ Taylor Carman, Heidegger's Analytic:

Interpretation, Discourse, and Authenticity in Being
}

translate Gerede by 'crosstalk' that is, talk at cross-purposes." 36

Jika Rede merupakan karakter yang esensial dari Dasein (manusia yang otentik), sebaliknya Gerede merupakan karakter esensial dari Dasman (manusia yang tidak otentik). Alih-alih memiliki karakter penyingkapan seperti Rede, Gerede justru memiliki karakter penutupan diri (berlawanan dengan karakter Dasein yang selalu mau membuka diri). Gerede tidak mengandaikan orang yang mengatakannya sebagai orang yang benarbenar memiliki pemahaman akan apa yang dikatakannya, sehingga yang menjadi fokus bukanlah pemahaman yang benar dari apa yang dibicarakan, melainkan pembicaraan itulah yang menjadi fokus utama. Richard Sembera mengatakan, "Crosstalk (Gerede) also emphasizes the spoken as such at the expense of the discussed, that is, at the expense of a real understanding of the talk, resulting in "talk for talk's sake." 37 Gerede juga bersifat tidak otentik, sebab ia membuat seseorang mengikuti arus tanpa adanya pengertian (verstehen). Heidegger berkata mengenai Gerede, "The case is so,

and Time (Cambridge: Cambridge University Press, 2003), 226.

${ }^{35}$ Sembera, Rephrasing Heidegger: A Companion to Being and Time, 101.

36 Ibid, 102.

${ }^{37}$ Ibid. 


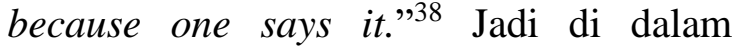
Gerede, sesuatu dikatakan karena banyak orang yang mengatakan hal yang sama, bukan karena pengalaman riil dari orang yang mengatakannya. Karena bersifat hanya ikut-ikutan, Gerede dengan sendirinya akan memperluas lingkarannya pada komunitas yang lebih luas dan pada akhirnya tidak jarang menjadi sebuah konsensus umum. Sembera mengatakan, "The announcement structure of crosstalk aims at creating the same superficial relation towards the discussed in the hearer as in the talker, so that crosstalk spreads itself in ever-widening circles and acquires the authority of general consensus." 39

Dari pembahasan di atas, dapat disimpulkan bahwa rede dalam filsafat Heidegger merupakan artikulasi-artikulasi yang komunikatif dan bermakna, meskipun belum dapat digolongkan sebagai sebuah bahasa sehari-hari (sprache). Rede juga merupakan karakteristik dari manusia otentik ala heidegger (dasein), yang selalu berusaha mencari "ada"-nya, salah satunya dengan cara menyingkapkan makna melalui komunikasi rede.

\section{Komparasi Konsep Bahasa Roh menurut Teologi Pentakosta dengan Konsep Rede dalam Filsafat Heidegger}

Dalam paragraf-paragraf berikutnya akan dibahas komparasi antara bahasa roh dalam teologi Pentakosta dengan konsep Rede dalam Filsafat Heidegger. Hubunganhubungan ini akan dibahas dengan penggolongan berdasarkan karakteristikkarakteristik Rede, dan kemudian membahas karakteristik-karakteristik tersebut dari sudut pandang bahasa roh dalam teologi Pentakosta.

Berbentuk Linguistik maupun NonLinguistik

Seperti yang telah dijelaskan sebelumnya, Rede di dalam filsafat Heidegger tidak selalu harus berbentuk linguistik, meskipun bisa juga berbentuk linguistik. Rede dapat digolongkan sebagai "pre-language," atau dasar dari terbentuknya bahasa. Namun demikian, Heidegger seringkali tidak memisahkan Rede dengan bahasa itu sendiri, dalam arti Rede memiliki konsep yang berdekatan dan tidak terpisahkan dengan bahasa.

Jika dihubungkan dengan bahasa roh, khususnya jenis yang tidak dapat dimengerti (glossolalia), bahasa roh dapat

\footnotetext{
${ }^{39}$ Sembera, Rephrasing Heidegger: A Companion to Being and Time, 103.
} 
tergolong sebagai pre-language. Bahasa roh jenis ini tidak bersifat linguistik dan kadang-kadang hanya merupakan artikulasi yang tidak jelas dan berulang. Namun demikian, bahasa roh tersebut memiliki potensi untuk ditafsirkan dengan karunia menafsirkan bahasa roh, sehingga bahasa roh yang tidak bersifat linguistik ini bisa menjadi linguistik dengan karunia menafsirkan bahasa roh. Rasul Paulus di dalam Alkitab juga selalu mendorong jemaat untuk menafsirkan bahasa roh, terutama bahasa roh yang digunakan secara publik. Dalam 1 Kor. 14:13, Paulus mengatakan, "Karena itu siapa yang berkata-kata dengan bahasa roh, ia harus berdoa, supaya kepadanya diberikan juga karunia untuk menafsirkannya."Hal ini juga berpadanan dengan konsep Heidegger bahwa Rede merupakan dasar dari penafsiran dan pernyataan. Hal ini tampak di dalam penerjemahan bahasa roh itu sendiri, sehingga menjadi sebuah tafsiran dan bahkan pernyataan nubuat. Sebaliknya, bahasa roh jenis xenolalia, atau berbentuk bahasa-bahasa bangsa asing yang dapat dimengerti juga tidak bertentangan dengan konsep Rede, sekalipun jenis bahasa roh ini berbentuk linguistik, karena seperti yang

\footnotetext{
40 Semeyna and Schmaltz, "Glossolalia Meets Glosso-Psychology: Why Speaking in Tongues
}

telah dijelaskan sebelumnya, Rede juga dapat berbentuk linguistik.

\section{Bersifat Komunikatif}

Karakteristik utama dari Rede adalah komunikatif. Namun komunikatif di sini bukan berarti harus dapat dimengerti oleh orang lain. Bahkan ketika maksud kita tidak dapat tersampaikan pada orang lain, asalkan kita telah berusaha mengkomunikasikan-nya, maka hal itu sudah termasuk komunikatif bagi Heidegger. Jika diaplikasikan pada bahasa roh, maka bahasa roh berada dalam paradoks antara komunikatif maupun tidak komunikatif. Bahasa roh bisa dikatakan komunikatif dalam konteks bahwa bahasa roh diucapkan sebagai bentuk komunikasi dengan Allah. Semeyna mengatakan, "Speaking in tongues is... a prayer language that affords supernatural communication with God that transcends both human and demonic understanding." 40 Walaupun orang yang sedang berbahasa roh mengatakan hal-hal yang non-linguistik, tetapi sesuai dengan pemahaman Heidegger tentang komunikatif, maka bahasa roh masih tergolong sebagai komunikatif karena orang yang mengatakannya mengerti bahwa ia sedang berdoa dan

Persist in Charismatic Christian and Pentecostal Gathering," 40. 
berkomunikasi dengan Tuhan. Seperti yang Rasul Paulus katakan di dalam 1 Kor. 14:2a, "Siapa yang berkata-kata dengan bahasa roh tidak berkata-kata kepada manusia, tetapi kepada Allah.” Orang yang berbahasa roh juga meyakini bahwa Tuhan pasti memahami artikulasi-artikulasi yang diungkapkan lewat bahasa roh tersebut. Oleh sebab itu bahasa roh bersifat komunikatif jika ditempatkan dalam konteks komunikasi dengan Tuhan.

Di sisi lain, bahasa roh juga dapat dikatakan sebagai non-komunikatif jika diletakkan dalam konteks sosial antar manusia. Bahasa roh memang bukan ditujukan untuk berkomunikasi dengan manusia yang lain, seperti yang dikatakan Rasul Paulus di dalam 1 Kor. 14:9, "Demikianlah juga kamu yang berkata-kata dengan bahasa roh: jika kamu tidak mempergunakan kata-kata yang jelas, bagaimanakah orang dapat mengerti apa yang kamu katakan? Kata-katamu sia-sia saja kamu ucapkan di udara!" Bahasa roh juga tidak semerta-merta dapat digunakan untuk berkomunikasi walaupun sudah ditafsirkan. Semeyna berkata, "Glossolalia is not used as means of communication between members of groups encouraging its use - although sometimes 'translation' by a leader is involved." 41

Dalam hal ini harus diakui, saat membahas soal Rede, Heidegger lebih berfokus pada komunikasi antar manusia, dan bukan komunikasi manusia dengan Tuhan. Oleh sebab itu, meskipun terdapat kemiripan konsep Rede dengan bahasa roh, tidak serta merta dapat dikatakan bahwa Rede identik dengan bahsa roh. Bahasa roh merupakan komunikasi dengan Allah (teologis), sedangkan Rede merupakan komunikasi antar manusia (bersifat antropologis).

\section{Bersifat Menyingkapkan}

Heidegger menekankan bahwa Rede harus bersifat menyingkapkan sesuatu, sebagai "articulation of intelligibility." Rede, sama seperti Logos, adalah penyingkapan terhadap Ada, di mana Heidegger menghubungkan karakteristik ini dengan manusia otentik (Dasein) yang selalu bersifat terbuka terhadap penyingkapan-penyingkapan mengenai "ada"-nya.

Bahasa roh juga memiliki karakteristik menyingkapkan. Bahasa roh yang dialami gereja perdana dipercaya sebagai sesuatu yang "diberikan oleh Roh Kudus" (Kis. 2:4). Seseorang berbahasa roh

\footnotetext{
${ }^{41}$ Ibid, 40.
} 
karena mempercayai bahwa Roh Kudus menyingkapkan sesuatu kepada dirinya sehingga ia berbahasa roh. Sekalipun bahasa roh yang keluar bukanlah jenis yang dapat dimengerti, tetapi kepercayaan bahwa bahasa roh itu sendiri adalah bentuk penyingkapan Sang Ada pada orang yang mengucapkannya telah menjadikan bahasa roh bersifat menyingkapkan.

\section{Merupakan Karakteristik Dasar dari}

\section{Dasein}

Heidegger menekankan bahwa Rede merupakan karakter yang esensial bagi manusia otentik (Dasein). Semua Dasein harus memiliki Rede, sebaliknya manusia yang tidak otentik (Dasman) tidak mungkin memiliki Rede. Dalam konteks bahasa roh menurut teologi Pentakosta, bahasa roh juga memiliki batasan keuniversalan. Seperti dijelaskan sebelumnya, menurut teologi Pentakosta bahasa roh merupakan karakter esensial dari orang-orang Kristen yang telah mengalami baptisan Roh Kudus. Sebaliknya orang Kristen yang tidak berbahasa roh menandakan dirinya belum mengalami baptisan Roh Kudus. Meskipun batasan keuniversalan antara Rede dan bahasa roh ini berbeda, namun terdapat kemiripan yaitu Rede dan bahasa roh samasama bersifat eksklusif dan bersyarat. Rede eksklusif dimiliki oleh manusia yang otentik, sedangkan bahasa roh eksklusif dimiliki oleh orang Kristen yang telah mengalami baptisan Roh Kudus.

\section{Dapat Dimengerti (Understandable)}

Heidegger mengatakan bahwa Rede harus dimengerti setidaknya oleh orang yang mengatakannya. Seperti contohnya seorang bayi mengungkapkan artikulasi yang non linguistik tetapi mengerti secara pasti bahwa ia sedang meminta pada ibunya untuk diberikan susu. Dalam hal ini, harus diakui bahwa bahasa roh tidak selalu dimengerti oleh orang yang mengatakannya. Meskipun orang tersebut berbicara bahasa roh dalam jenis yang dapat dimengerti orang lain (xenolalia), pada kenyataannya saat orang tersebut mengatakan bahasa-bahasa bangsa asing tersebut, ia tidak mengerti apa yang dikatakannya dan mengapa mereka mengatakan hal itu, karena sebelumnya mereka tidak pernah mempelajari bahasa tersebut. Di dalam Alkitab, Rasul Paulus sendiri mengafirmasi bahwa seseorang yang berbahasa roh tidak mengerti apa yang mereka katakan. 1 Kor. 14:2 berbunyi, "Siapa yang berkata-kata dengan bahasa roh tidak berkata-kata kepada manusia, tetapi kepada Allah. Sebab tidak ada seorangpun yang mengerti bahasanya; oleh 
Roh ia mengucapkan hal-hal yang rahasia." (LAI)

Walaupun pada umumnya orang yang berbahasa roh tidak mengerti apa yang dikatakannya saat berbahasa roh, orang yang berbahasa roh tersebut ada di dalam keadaan yang sadar. Penelitian terbaru menurut Seymena, menyatakan bahwa orang-orang yang berbahasa roh sepenuhnya ada dalam keadaan sadar meskipun mereka tidak mengerti apa yang mereka katakan. ${ }^{42}$ Jadi bahasa roh bukan hal yang dilakukan seseorang dalam keadaan tidak sadar. Oleh sebab itu ketidakmengertian orang tersebut akan apa yang dikatakannya bukan dikarenakan ia sedang ada dalam keadaan trance.

Ketidakmengertian yang dialami secara sadar ini menjadikan bahasa roh unik jika dibandingkan dengan Rede. Dalam konsep Rede, seseorang sadar dan mengerti apa yang ia katakan meskipun ekspresi pengungkapannya bisa berbentuk nonlinguistik. Sedangkan di dalam bahasa roh, seseorang sadar tetapi tidak mengerti apa yang ia katakan dan ekspresi pengungkapannya bisa berbentuk baik linguistik (xenolalia) maupun nonlinguistik (glossolalia). Tetapi harus diingat bahwa bahasa roh adalah pengalaman iman,

${ }^{42}$ Ibid, 41. sehingga walaupun orang yang berbahasa roh tidak mengerti apa yang ia katakan, tetapi di dalam kesadarannya ia meyakini bahwa apa yang ia katakan adalah doa dan puji-pujian kepada Allah.

Gerede dan Bahasa Roh: Sebuah Perspektif terhadap Praktik Bahasa Roh dalam Gereja-Gereja Pentakosta Masa Kini

Bahasa roh masih dipraktikkan sampai zaman sekarang oleh gereja-gereja Pentakosta. Bahasa roh dipandang sebagai tanda utama (initial evidence) bahwa seseorang telah dibaptis oleh Roh Kudus. Lebih lagi, di zaman sekarang masih terdapat kaum Pentakosta yang menganggap bahwa bahasa roh menjadi sebuah ukuran terhadap pertobatan seseorang, bahkan kedekatan hubungan seseorang dengan Tuhan. Scott Semenyna berkata, "Put another way, the positive affect associated with glossolalia encourages intuitive ways of thinking that only strengthens the belief in its power and efficacy as a means to communicate more deeply with God." ${ }^{43}$ Ditambah lagi, praktik bahasa roh di zaman sekarang dapat berlangsung secara publik dalam pertemuan-pertemuan ibadah. Ketika bahasa roh ditempatkan secara publik,

${ }^{43}$ Ibid, 42. 
secara otomatis akan terlihat siapa saja yang tidak dapat berbahasa roh. Menyambung tentang ukuran-ukuran kerohanian yang dijelaskan sebelumnya, maka orang-orang yang tidak dapat berbahasa roh akan merasa inferior dalam kerohanian dibandingkan seseorang yang bisa berbahasa roh. Perasaan inferior ini menimbulkan sebuah kerinduan untuk bisa berbahasa roh. Bukan hanya supaya dapat lebih dekat dengan Allah, melainkan juga supaya dapat diterima dalam komunitas gereja Pentakosta. Oleh sebab itu orang-orang yang belum dapat berbahasa roh akhirnya memutuskan untuk mengikuti arus dengan cara menirukan bunyi dan lafal dari bahasa roh yang sering terdengar di gereja-gereja Pentakosta. Semeyna menggolongkan praktik-praktik peniruan seperti ini sebagai social learning, dan bukan karunia Roh Kudus. Praktik-praktik ini merupakan sebuah bentuk kerinduan dari seseorang untuk diterima dalam komunitasnya, dan pembelajaran sosial dapat terjadi dalam hal ini, yaitu mereka meniru apa yang dikatakan oleh orang-orang di sekitar mereka. ${ }^{44}$

Bahkan saat bahasa roh dipraktikkan dalam doa-doa pribadi jemaat, hal itu tidak dapat dilepaskan dari konteks sosialnya. Di dalam doa pribadi, jemaat mempraktikkan apa yang telah mereka dengar dan pelajari di dalam pertemuanpertemuan ibadah. Setelah mereka mempraktikkan bahasa roh dalam doa-doa pribadi, mereka juga akan terdorong untuk mempraktikkannya kembali di komunitas gereja Pentakosta untuk mendapatkan validasi atas pengalaman-pengalaman doa pribadinya. Semeyna mengatakan, "They also likely found validation of their experience with re-exposure in their church community, as well as encouragement and acceptance of their 'gift' within the congregation." 45

Praktik bahasa roh seperti di atas memiliki kemiripan memiliki kemiripan dengan konsep Gerede menurut Heidegger. Seperti dijelaskan sebelumnya, Gerede merupakan karakteristik dari manusia yang inotentik. Tidak seperti Rede, Gerede tidak bersifat menyingkapkan, bahkan justru bersifat menyembunyikan, karena Gerede tidak berusaha untuk menggali dan menyingkapkan kebenaran yang sesungguhnya. Gerede lebih mengacu kepada ucapan-ucapan yang mengikuti arus, tanpa memahami mengapa mereka mengatakan hal-hal tersebut, dan juga tanpa

${ }^{44}$ Ibid, 41.

${ }^{45}$ Ibid.

91 Copyright C 2019, Dunamis, ISSN 2541-3937 (print), 2541-3945 (online) 
melakukan analisa lebih jauh kebenaran hal-hal yang diucapkan.

Tanpa memahami konsep bahasa roh dengan benar, orang-orang ini hanya ingin diterima oleh komunitasnya dengan cara memiliki kemiripan dengan mereka. Pada kasus ini, replikasi dapat terjadi. Mereka meniru bahasa roh yang seringkali mereka dengar dari orang lain, dan dengan demikian menjadi Gerede. Hardiman berpendapat bahwa salah satu contoh dari Gerede memang adalah replikasi tindakan maupun ucapan orang lain. Beliau memberi contoh sebagai berikut, "Berita tentang rumah hantu di kawasan Pondok Indah Jakarta menyeret ratusan orang untuk melihatnya. Saat ditanya mengapa datang kesitu, orang tak bisa memberikan alasan selain hanya untuk melihat seperti orangorang lain melihat."46

Sejalan dengan itu, orang-orang yang mereplikasi bahasa roh juga biasanya tidak dapat menjelaskan fenomena yang terjadi tersebut. Dalam praktik seperti ini, bahasa roh lebih mendekati konsep Gerede dalam karakteristik yang menyembunyikan. Orang tersebut tidak dapat mempertanggung-jawabkan apa yang ia katakan sebagai gerakan Roh Kudus karena mereka hanya meniru apa yang orang lain

\footnotetext{
${ }^{46}$ Hardiman, Heidegger Dan Mistik Keseharian, 95.
}

katakan. Ketika mengucapkan bahasa roh sebagai Gerede, "pengobrol berbicara tanpa sadar tentang apa saja, tentang sesuatu yang hanya merupakan unsur anonim dalam gerak naik turunnya suasana hati percelotehan anonim yang tidak terkendali."47 Bahasa roh bukan lagi sesuatu yang menyingkapkan sang pembicara tentang Sang Ada, yang dalam hal ini Allah, melainkan semata-mata menjadi percelotehan yang membingungkan.

Hal ini merupakan evaluasi bagi gereja-gereja Pentakosta yang mewajibkan semua orang Kristen untuk menerima karunia bahasa roh sebagai tanda awal baptisan Roh Kudus. Harus diakui, praktik bahasa roh di gereja-gereja Pentakosta masa kini jelas memiliki perbedaan yang signifikan dengan praktik bahasa roh di dalam Perjanjian Baru. Pertama, di dalam Perjanjian Baru tidak dituliskan secara jelas bahwa jemaat Kristen harus dapat berbahasa roh. Pengalaman-pengalaman berbahasa roh di dalam Perjanjian Baru terjadi begitu saja tanpa tekanan sosial, sehingga kemungkinan untuk meniru bahasa roh orang lain sangatlah kecil. Di gereja Pentakosta saat ini bahasa roh telah digunakan sebagai identitas sehingga

${ }^{47}$ Ibid, 94. 
menyebabkan tekanan sosial yang tak terhindarkan. Bahasa roh bisa menyebabkan seseorang menjadi tidak otentik, dan sekadar menjadi Gerede yang tidak bermakna. Kedua, di dalam Perjanjian Baru, karunia bahasa roh yang dipraktikkan jemaat mula-mula memiliki after-effect yang mempermuliakan nama Tuhan, di mana Kisah Para Rasul 2 melaporkan bahwa orang-orang yang mendengarnya menjadi takjub. Sebaliknya, praktik bahasa roh di masa kini bukan membuat orang takjub lagi, melainkan membuat orang semakin bingung. ${ }^{48}$ Karakteristik bahasa roh bukan lagi menyingkapkan (Rede) melainkan malah menyembunyikan (Gerede). Oleh sebab itu perlu dipertanyakan kembali apakah di zaman sekarang ini, gereja-gereja Pentakosta masih perlu memaksakan seseorang untuk berbahasa roh sebagai tanda baptisan Roh Kudus? Di sisi lain di zaman sekarang sudah terdapat Alkitab yang merupakan wahyu Allah yang khusus dan universal bagi semua orang Kristen. Karunia bahasa roh, dengan demikian, tidak perlu dipaksakan tetapi juga tidak boleh dilarang, seperti nasihat Paulus dalam I Kor. 14:39, "Karena itu, saudara-saudaraku, usahakanlah dirimu untuk memperoleh

\footnotetext{
48 Semeyna and Schmaltz, "Glossolalia Meets Glosso-Psychology: Why Speaking in Tongues
}

karunia untuk bernubuat dan janganlah melarang orang yang berkata-kata dengan bahasa roh.” (TB-LAI)

\section{Kontribusi Penelitian}

Kontribusi terhadap Konsep Rede dalam filsafat Heidegger

Penulis menganalisa bahwa studi komparasi terhadap konsep bahasa roh dan konsep Rede memberikan setidaknya dua kontribusi konseptual terhadap konsep Rede dalam filsafat Heidegger. Kontribusi pertama, konsep bahasa roh menyingkapkan sebuah perspektif baru bahwa ada fenomena spiritual yang mirip dengan konsep Rede dalam pemikiran Heidegger. Seperti yang telah dijelaskan sebelumnya, selama ini Rede hanya dihubungkan dengan pengalaman rasional dan bukan pengalaman imani. Ini disebabkan karena Rede merupakan konsep filsafat, dan bukan konsep teologis.

Selain itu, meski Heidegger seringkali menunjukkan fokus dan ketertarikannya akan konsep Rede, kurang adanya contoh yang aplikatif membuat konsep Rede sulit dipahami lebih lanjut. Setidaknya dengan studi komparasi ini para filsuf yang mempelajari Heidegger dapat memperhatikan fenomena yang mirip

Persist in Charismatic Christian and Pentecostal Gathering,", 42. 
dengan itu, yaitu fenomena spiritual bahasa roh, yang diharapkan juga dapat membuka pikiran para filsuf kepada ranah teologis.

Kontribusi yang kedua, praktik bahasa roh memperkuat konsep yang dibangun Heidegger mengenai Rede. Perlu diketahui bahwa konsep yang dibangun Heidegger mengenai Rede juga mendapatkan beberapa kritik di dalam bidang filsafat. Cristina Lafont mengkritik bahwa apa yang dijelaskan Heidegger sebagai Rede sebenarnya tidak tepat disebut Rede, karena karakteristik Rede, menurut Lafont, harus bersifat linguistik. Lafont mengkritik bahwa Heidegger menggunakan kata Rede karena secara linguistik, Rede berarti percakapan atau diskursus. Percakapan atau diskursus, dalam pengertian umum selalu menggambarkan percakapan linguistik, bukan pralinguistik. $^{49}$ Oleh sebab itu, Lafont menganggap menggunakan kosakata Rede untuk menggambarkan apa yang dimaksud Heidegger adalah kurang cocok. Demikian juga Steven Crowell menganggap jika Rede tidak bersifat linguistik, maka mustahil bahwa percakapan tersebut dapat ditafsirkan, "If, on the other hand, discourse is radically distinct from language, how are

\footnotetext{
${ }^{49}$ Cristina Lafont, Heidegger, Language, and World Disclosure, trans. Graham Harman (Cambridge: Cambridge University Press, 2000), 246-247.
}

we to distinguish it from the kind of 'appropriation' accomplished in interpretation? Why is it considered an existentiale at all?"50

Studi komparasi Rede dan bahasa roh dapat menjawab dua kritik di atas. Kritik Lafont bahwa Rede selalu bersifat linguistik dapat dibantah dengan melihat fenomena bahasa roh, baik di gereja perdana maupun gereja-gereja Pentakosta masa kini. Rede yang dapat bersifat nonlinguistik dan linguistik tercermin dalam praktik bahasa roh yang dapat berupa vocal utterances yang berbentuk non-linguistik (glossolalia) dan juga dapat berbentuk linguistik (xenolalia). Demikian juga praktik penafsiran bahasa roh yang terjadi di gereja perdana menjawab kritik Crowell mengenai ketidakmungkinan penafsiran jika Rede bersifat non-linguistik.

\section{Kontribusi Penelitian: Kontribusi terhadap Konsep Bahasa Roh dalam Teologi Pentakosta}

Berikut akan dijabarkan tiga kontribusi yang diberikan studi komparasi dalam artikel ini terhadap konsep bahasa roh dalam teologi Pentakosta. Kontribusi pertama, studi komparasi ini menempatkan

\footnotetext{
${ }^{50}$ Steven Crowell, Normativity and Phenomenology in Husserl and Heidegger (Cambridge: Cambridge University Press, 2013), 229.
} 
bahasa roh sebagai bentuk keterbukaan terhadap Allah dan wahyu-Nya (logos), sehingga menjadi pengalaman yang subyektif dan personal. Rede merupakan mode of being dari Dasein, yang bercirikan keterbukaan atau penyingkapan terhadap dunia. Namun bahasa roh, lebih dari itu adalah pengalaman iman, oleh sebab itu bukan hanya bercirikan keterbukaan terhadap dunia, melainkan juga keterbukaan terhadap Allah dan wahyuNya. Ini mengindikasikan bahwa bahasa roh sebagai bentuk Rede harus bercirikan keterbukaan pada Allah dan wahyu-Nya. Tanpa ada keterbukaan ini, mustahil seseorang dapat berbahasa roh.

Perlu diketahui bahwa di zaman sekarang banyak pihak dari teolog-teolog non-Pentakosta yang mengkritik praktik bahasa roh. Beberapa menilai bahwa pengalaman ini tidak Alkitabiah, atau sudah berhenti sama sekali di zaman sekarang. Wayne Grudem mengatakan bahwa praktik bahasa roh di zaman sekarang merupakan sesuatu yang sulit ditemukan dasarnya di dalam Alkitab, walaupun ia sendiri tidak menganut pandangan cessasionist. ${ }^{51}$

Namun jika dilihat dari sudut pandang bahwa bahasa roh adalah bentuk

\footnotetext{
${ }^{51}$ Wayne Grudem, Systematic Theology: An Introduction to Bible Doctrine (Grand Rapids: Zondervan Publishing House, 1994), 103. Di Indonesia, salah satu tokoh yang keras menentang
}

keterbukaan seseorang pada Allah dan wahyu-Nya, maka praktik bahasa roh adalah sesuatu yang bersifat subyektif dan tidak dapat dinilai oleh orang lain. Juga ketika seseorang telah terlebih dahulu menutup diri terhadap pengalaman ini, maka mustahil mereka dapat mengalami pengalaman berbahasa roh.

Kedua, studi komparasi ini memberikan awasan pada praktik bahasa roh masa kini terhadap ketidakotentikan dan pemalsuan bahasa roh. Sesuai pembelajaran mengenai Rede, bahasa roh harus merupakan pengalaman otentik, karena Rede sendiri merupakan mode of being dari Dasein, manusia yang otentik. Oleh sebab itu bahasa roh harus terjadi secara natural, tidak dibuat-buat atau dipalsukan, apalagi dipelajari. Bahasa roh harus merupakan hasil dari keterbukaan terhadap Allah dan wahyu-Nya. Lebih lagi, sebagai pengalaman yang otentik, bahasa roh tidak boleh menjadi sesuatu yang dipaksakan kepada orang lain sebagai sebuah standar kerohanian. Ketika bahasa roh sudah dipaksakan sebagai sebuah kewajiban pada seseorang, maka bahasa roh akan berubah menjadi Gerede. Memaksakan pengalaman berbahasa roh

relevansi bahasa roh di zaman sekarang adalah Pdt DR. Stephen Tong, lihat Stephen Tong, Baptisan Dan Karunia Roh Kudus (Jakarta: Lembaga Reformed Injili Indonesia, 1995), 74. 
juga dapat mendorong seseorang untuk memalsukan pengalaman berbahasa roh, sehingga bahasa roh tidak otentik lagi.

Ketiga, studi komparasi ini menunjukkan kekhasan bahasa roh dibanding pengalaman-pengalaman ekstatis yang serupa. Bahasa roh juga tidak boleh dipandang hanya sebagai pengalaman ekstatis. Jika hanya dipandang sebagai pengalaman ekstatis, maka bahasa roh tidak ada bedanya dengan pengalamanpengalaman esktatis serupa yang dialami agama-agama lain atau mistis-mistis tertentu. Sebaliknya bahasa roh itu memiliki aspek rasional, sebagaimana dikonfirmasi dengan kemiripan konsep bahas roh dengan konsep Rede. Dalam praktiknya, bahasa roh juga dapat dimulai dan dihentikan oleh sang pembicara itu sendiri. Berbeda dengan pengalaman trance dan ekstatis, pengalaman bahasa roh masih melibatkan kesadaran dan rasio si pembicara. Ini merupakan satu faktor pendukung bahwa bahasa roh tepat untuk digolongkan sebagai pengalaman yang mirip dengan Rede, namun tetap berbeda, karena bahasa roh berhubungan dengan iman orang yang melakukan hal tersebut. Di sini penulis sama sekali tidak menyamakan

\footnotetext{
${ }^{52}$ Heidegger meyakini ada tiga cara berada (mode of being) Dasein dalam dunia, yaitu suasana hati (Befindlichkeit), pemahaman (Verstehen), dan
}

Rede dengan fenomena berbahasa roh, penulis meyakini bahwa fenomena berbahasa roh bersifat adikodrati dan berasal dari Tuhan, sedangkan Rede murni berasal dari pikiran manusia.

\section{KESIMPULAN}

Secara garis besar, persamaan esensial Rede dan bahasa roh terletak di dalam eksistensi keduanya sebagai "cara berada" (mode of being) manusia di dalam dunia. ${ }^{52}$ Rede dan bahasa roh sama-sama merupakan ekspresi eksistensial manusia untuk menyingkapkan kediriannya yang otentik kepada dunia melalui komunikasi yang pra-reflektif dan pra-bahasa. Meskipun demikian harus disadari bahwa di antara keduanya terdapat perbedaan yang mendasar. Keduanya didasari oleh perspektif (worldview) yang berbeda dalam cara beradanya di dalam dunia ini. Cara berada orang yang berbahasa roh didasari oleh perspektif iman, dalam hal ini adalah iman Kristen. Bahasa roh tidak mungkin terpisah dari iman Kristen itu sendiri, dan inilah yang membedakan bahasa roh versi teologi Pentakosta dengan ungkapanungkapan pra-reflektif dan pra-bahasa lainnya (contohnya fenomena ekstasis

percakapan (Rede), lihat Heidegger, Being and Time, 28-34. 
dalam agama lain). ${ }^{53}$ Perspektif iman Kristen yang eksklusif dan terbatas ini menjadikan fenomena bahasa roh bukan hanya otentik, tetapi juga memiliki kekhasannya sendiri sebagai sebuah pengalaman iman. Pengalaman iman ini dapat disebut sebagai anugerah khusus yang dimiliki oleh kaum Pentakosta, atau yang seringkali mereka sebut sebagai "second blessing." $" 54$ Pengalaman iman ini tidak lantas menjadikan bahasa roh lepas dari cara berada di dalam dunia ini, sehingga mengakibatkan keterpisahan antara yang kudus dan sekuler. Sebaliknya pengalaman iman ini dipakai sebagai kacamata / perspektif mereka memandang dunia ini.

\section{DAFTAR PUSTAKA}

Bruner, Fredrick Dale. A Theology of the Holy Spirit: The Pentecostal Exprerience and the New Testament Witness. Michigan: Eerdmans Publishing Company, 1982.

Budiselic, Ervin. "Glossolalia: Why Christians Can Speak in Tongues in a Church Service without Interpretation." Kairos Evangelical

\footnotetext{
${ }^{53}$ David A. Swincer, dalam bukunya menolak anggapan orang-orang yang menyamakan pengalaman bahasa roh dengan pengalamanpengalaman ekstatis yang terjadi dalam agamaagama pagan kuno maupun pengalaman mistis Yunani. Ia mengklaim bahwa pengalaman berbahasa roh adalah pengalaman yang khusus dialami oleh orang-orang Kristen di sepanjang zaman, lihat David A. Swincer, Tongues Volume 1: Confused by Ecstasy (Adelaide: Integrity Publications, 2016), 436.

${ }^{54}$ Kaum Pentakosta mempercayai bahwa di dalam pertumbuhan iman Kristen seseorang, ada dua
}

Journal of Theology 10, no. 2 (2016): 179.

Carman, Taylor. Heidegger's Analytic: Interpretation, Discourse, and Authenticity in Being and Time. Cambridge: Cambridge University Press, 2003.

Carothers, Warren F. The Baptism with the Holy Ghost and the Speaking in Tongues. Zion City, IL, 1906.

Crowell, Steven. Normativity and Phenomenology in Husserl and Heidegger. Cambridge: Cambridge University Press, 2013.

Dodson, Jacob D. "Gifted for Change: The Evolving Vision for Tongues, Prophecy, and Other Charism in American Pentecostal Church." Studies in the World Christianity 17, no. 1 (2011): 56.

Goodman, Felicitas D. Speaking in Tongues: A Cross-Cultural Study of Glossolalia. Oregon: WIPF\&Stock, 1972.

Gorner, Paul. Heidegger's Being and Time: An Introduction. Cambridge: Cambridge University Press, 2007.

Grudem, Wayne. Systematic Theology: An Introduction to Bible Doctrine. Grand Rapids: Zondervan Publishing House, 1994.

Hardiman, F. Budi. Heidegger Dan Mistik 
Keseharian. Jakarta: Kepustakaan Populer Gramedia, 2016.

Heidegger, Martin. Being and Time. Edited by John Macquarrie and Edward Robinson. Oxford: Basil Blackwell, 1962.

Hocken, Peter. The Challenges of the Pentecostal, Charismatic and Messianic Jewish Movement: The Tension of the Spirit. Farnham: Ashgate Publishing Limited, 2009.

Hudson, Neil. "Dealing with the Fire: Early Pentecostal Responses to the Practices of Speaking in Tongues and Spoken Prophecy." Journal of the European Pentecostal Theological Association 28, no. 2 (2008): 145157.

Keener, Craig S. Gift and Giver: The Holy Spirit for Today. Michigan: Baker Academic, 2001.

_. Spirit Hermeneutics: Reading Scripture in Light of Pentecost. Michigan: Wm. Eerdmans Publishing Co, 2016.

Lafont, Cristina. Heidegger, Language, and World Disclosure. Edited by Graham Harman. Cambridge: Cambridge University Press, 2000.

Menzies, Robert P. "The Role of Glossolalia in Luke-Acts." AJPS 15, no. 1 (2012): 49.

Menzies, William P., and Robert P. Menzies. Roh Kudus Dan Kuasa: Dasar-Dasar Pengalaman Pentakostal. Batam: Gospel Press, 2005.

Okrent, Mark. "On Layer Cakes: Heidegger's Normative Pragmatism Revisited." In Pragmatic Perspectives in Phenomenology, edited by Ondrej Svec and Jakub Capek. New York: Routledge, 2017.
Parham, Sarah E. The Life of Charles F. Parham, Founder of the Apostolic Faith Movement. Baxter Springs, KS: Apostolic Faith Bible College, 1930.

Sembera, Richard. Rephrasing Heidegger: A Companion to Being and Time. Ottawa: The University of Ottawa Press, 2007.

Semeyna, Scott, and Rodney Schmaltz. "Glossolalia Meets GlossoPsychology: Why Speaking in Tongues Persist in Charismatic Christian and Pentecostal Gathering." Skeptic Magazine 17, no. 4 (2012): 41.

Siahaan, Harls Evan R. "Refleksi Alkitabiah Fenomena Glossolalia." Jurnal Antusias 2, no. 1 (2012): 160179. Accessed October 22, 2019. https://sttintheos.ac.id/ejournal/index.php/antusias/article/vie w/67.

Sign, Alexander O. Speaking in Tongues. Bloomington: AuthorHouse, 2014.

Simanullang, Gonti. "Baptism in the Holy Spirit: A Phenomenological and Theological Study." Melbourne College of Divinity, 2012. Accessed October 22, 2019.

https://repository.divinity.edu.au/931/

Suanglangi, Hermanto. "Bahasa Roh: Apa Dan Bagaimana?” Jurnal Jaffray 2, no. 1 (April 1, 2005): 17.

Swincer, David A. Tongues Volume 1: Confused by Ecstasy. Adelaide: Integrity Publications, 2016.

Tong, Stephen. Baptisan Dan Karunia Roh Kudus. Jakarta: Lembaga Reformed Injili Indonesia, 1995.

Unger, Merrill F. The Baptism and Gifts of the Holy Spirit. Chicago: Moody Press, 1974. 
Dunamis: Jurnal Teologi dan Pendidikan Kristiani, Vol. 4, No. 1, Oktober 2019

99 Copyright $\subset$ 2019, Dunamis, ISSN 2541-3937 (print), 2541-3945 (online) 